\title{
TACC2 wt Allele
}

National Cancer Institute

\section{Source}

National Cancer Institute. TACC2 wt Allele. NCI Thesaurus. Code C54540.

Human TACC2 wild-type allele is located within $10 \mathrm{q} 26$ and is approximately $265 \mathrm{~kb}$ in length. This allele, which encodes transforming acidic coiled-coil-containing protein 2 , is putatively involved in the organization of centrosomal microtubules during the cell cycle. Decreased expression of the TACC2 gene is associated with the progression of breast tumors. 